\title{
Glitch as the Representation of the Uncanny in Oxenfree (2016)
}

\section{Agata Waszkiewicz}

Maria Curie-Skłodowska University in Lublin agata.anna.waszkiewicz@gmail.com | ORCID: 0000-0002-2340-4812

\begin{abstract}
The Gothic engages its audiences in the constant play by evoking the same anxieties in its audience and its protagonists. Furthermore, it could be argued that transgressions are its immanent feature. The supernatural elements, with the strong emphasis on the ghosts, often create the feeling of the uncanny, which, defined by the mixing of the familiar with unfamiliar, is not unknown to the video game genre. In the paper I offer a close reading of $0 x e n f r e e(2016)$, demonstrating the Gothic elements featured in the game, concentrating on how the uncanny manifests through the use of the audiovisual glitch.
\end{abstract}

Keywords: $0 x e n f r e e$, glitch, transgressive player, uncanny 



\section{Introduction}

The Gothic novel as such emerged as a separate genre in England during the second half of the $18^{\text {th }}$ century in reaction to the rationalism of the Age of Enlightenment. However, many of its hallmark tropes and ideas are still omnipresent in today's fiction, across many media (Edwards, 2017, p. 71). With the themes of mystery, terror, and horror seemingly being the most universally fascinating for the readers across the countries and centuries, it is not surprising that the supernatural themes, including haunted houses, ghosts, or vampires, have never lost their popularity. This is visible when one considers the reboots and retelling of classic stories with the release of highly anticipated Vampyr and the newest official Lovecraftian retelling of the Call of Cthulhu RPG video game in 2018, or the release of Blair Witch in 2019. However, the Gothic does not need to involve supernatural elements. What seems even more characteristic is the theme of returning past, the instability of memories, psychology of the villain and criminal, but also subversion and play with opposites, especially with gender roles understood in a binary manner, which allow to point out the transgressive qualities of the Gothic (Spooner, McEvoy, 2007, p. 1).

The Gothic plays a game with its recipients - whether they are literary readers, the audience of movies and TV series, or video game players by letting them share the uncertainty with main characters. The texts hide certain elements, bend the rules of what is known and expected, causing the players to share the characters' anxieties. The transgressiveness encountered in the Gothic - understood here as crossing of the boundaries of the genre and of the expectations towards the relationship between the text and its user - seems to share certain similarities with the video game medium. The latter, due to its interactive nature, requires a higher level of engagement on the part of players. Therefore, players always have two roles: on the one hand, as active participants deciding on the behavior and decisions of the characters they direct, but on the other hand, as passive recipients of the story created by the game developers. Crossing boundaries is therefore inscribed in the character of the game one could even be tempted to say that the player is a ghost haunting technology, an invisible poltergeist supporting the main character's actions. 
The Gothic adapted well to the video game medium with the very first horror game, Haunted House, released for Atari as early as in 1981 (Therrien, 2009, p. 30). Currently, horror and Gothic themes are easy to find among different game genres (Therrien, 2009, p. 32). This popularity could be linked to the particular, active form of engagement of that medium.

The participatory character of the video game player's experience has already been well researched (Aarseth, 2007). Currently, it seems to be quite common for publishers to advertise their titles by focusing on how much freedom they give to the players. Thus, the so-called "open world" or "sandbox" games offer a vast number of quests without a predefined order in which they should be played, while many narrative games promise that the players will have agency over the events and be responsible for the endings. On the other hand, the role-playing genre developed a robust system of customizing one's own character, giving players full control over the appearance of their characters. However, these games are often criticized by players who felt disappointed upon finding out the many constraints these games do pose on the players. In fact, it is difficult to imagine a game without them. Such a thing - or as close to it as one could imagine - might only be possible in a tabletop role-playing game, where the story is equally constructed by the participants and the game master, rather than in a video game, which is programmed and, thus, based on a set of rules. Contrary, perhaps, to the intuition, this does not mean that video games are resistant to transgressions.

In the article, I wish to explore the connection between the aesthetic glitch and the Gothic uncanny, pointing to the ways in which this connection manifests in video games. In order to do this, I analyze an independent game Oxenfree (2016) by Night School Studio. This short, narrativedriven game combines elements of the Gothic mystery with a coming of age story. With unique aesthetics, its primarily mechanic relies on the dialogue choices and limited exploration. I will focus primarily on the supernatural element - namely the ghosts - and the audiovisual glitch utilized in its representation. My analysis will show the usefulness of the glitch perceived as a symbol of transgression not only in the Gothic setting but in the video game medium in general. Finally, I will discuss the ludic transgressiveness offered by the Oxenfree ending. 


\section{Ghosts and Technology in Oxenfree}

The critically acclaimed Oxenfree was released in 2016 by the independent Night School Studio. Designed in the 2.5D format where three-dimensional figures move in two-dimensional spaces, it has immediately recognizable aesthetics with simple character silhouettes in soft colors. Embedded in the tradition of point-and-click and adventure genres, which place a strong emphasis on the narrative, history and character development, the main mechanics of the game rely on exploration and dialogue choices. This means that conversations between characters happen outside of the cutscenes and are naturally woven into the gameplay. Through their choices, the players, to a small degree, are able to influence the ending And after finishing the game, the players are presented with diagrams that compare them with the other players.

The player controls Alex, a teenager who ventures on a trip with her friends to spend a weekend on the Edwards Island, which previously was a military base, but now, after its last inhabitant died, it is abandoned and, presumably, haunted. The other characters include Alex' best friend Ren, her new stepbrother Jonas, whom she hardly knows at the beginning of the game, Nony, who can become Ren's love interest, and Clarissa, who used to date Alex's late brother Michael. Unsurprisingly, the latter's death plays a crucial part in the game, and strongly affects both Alex and Clarissa, neither of whom have managed to deal with the loss. Thus, Michael becomes the first ghost of the game, introducing the ominous flashbacks and adding the elements of nostalgia, two common parts of the Gothic genres. The game soon introduces its main supernatural plot - it turns out that the teenagers did not choose their trip destination by accident, but came in search of the island's secrets. The grim, haunted, empty mansion - another Gothic trope - turns out to belong to the recently deceased Maggie Adler who for years has been the island's only inhabitant. What has brought the group of friends here, though, is the rumors concerning the local caves.

Reluctantly at first, Alex decides to assist Ren and Jonas' investigation, just to discover that the stories have been true. Using their radio, they manage to trigger and open an interdimensional rift, causing them and their friends to lose consciousness, only to wake up transported to different locations on the island. The events at the cave cause a number of supernatural 
occurrences: telekinesis, time loops, ghostly possessions resulting in - temporary - deaths, transgressions between alternative versions of the universe, and radio wave distortions. Later it turns out that the ghosts are the souls of the crewmembers of USS Kanaloa submarine, which was sunk as a result of Maggie Adler's error. The entire crew was transferred to another dimension where they were imprisoned for many years. Vengeful spirits trying to break free from their prison, even, or especially, when human lives are in danger, is one of the common themes in the Gothic genre.

In robotics, the uncanny valley, a term coined by Masahiro Mori (1970, p. 33), refers to the unpleasant sensation felt by humans in contact with the androids which, while humanoid, do not manage to precisely duplicate the human features. With the video game software allowing for more and more realistic graphics, that effect can often become a part of the players' experiences with the game. However, this is just one of the ways in which the uncanny has been associated with technology. Especially in the 1990s rapid technological advancements caused the fear of the unknown future in which computers, robots, and androids would become so advanced that humanity would no longer be able to control them (Allué, 2003, p. 18). The scientific dream of crossing the boundary between the human and the machine is not necessarily just a dream anymore, as shown through, among others, Katherine Hayles' writing on the posthuman (1999). The motif of such transgressions, paired with the fear of contaminated and deformed technology, is, in turn, visible in dystopian visions appearing in many science fiction franchises both in the East (e.g. Ghost in the Shell, 1995) and the West (e.g. The Matrix, 1999).

In these narratives, the role of glitch is particularly interesting. The Matrix, for example, famously incorporated glitches to signal the occurrence of the transgression and the moment when the two environments failed to merge smoothly. Glitch, as an audiovisual representation of the system's malfunction, adequately illustrates the transition between the two states, between "a real and unreal" (Betancourt, 2017, p. 104). Furthermore, paradoxically, glitch brings to the foreground what is usually invisible (p. 7). However, the visible failure usually does not completely stop the digital system; it is rather a signal warning about the error as the system failure remains invisible (p. 44). Therefore, it is important to note the ontological difference between the spontaneous glitch and the 
Morandi's "glitch-alike" or Menkman's "domesticated glitch" identified with the artistic context and the deliberate construction of the glitch-like audiovisual representation (2017, p. 87).

Such artistic interferences can be thus interpreted as an attempt to take control of what, by definition, is uncontrollable, to adopt the error as a part of a larger whole, an attempt to tame what is unfamiliar. As a result, a new type of intentional interference is created, one that no longer is an accident, and, thus, at the same time, ceases to be a mistake, changing its ontological status and defying its original purpose. The glitch then is a symbol of (its own) transgression from one state to the other. The use of error becomes art in its own right and points to another way in which video games engage players.

The aforementioned transgressive play can involve the exploitation of the first type of glitches, understood as actual errors in the coding, which could entrap the opponent in the corner and therefore reduce the threat they pose. It is the second type, though, which is of importance in the case of Oxenfree.

There, the glitch is the visual representation of the breaches between the worlds, and, therefore, it accompanies the ghosts' presence. On the one hand, the visual glitch distorts the image, disorienting the player and forcing them to share the characters' anxiety, but simultaneously the glitch represents the rift between the worlds and the incomprehensible nature of the other realm. The glitches vary in size and form, with some softer disturbances applied to the image in the moments of tension between the characters, allowing for speculation as to whether they were the results of personal differences or supernatural interferences. On the other hand, the audiovisual glitch of the radio waves is introduced as a gameplay mechanic. While telling each other ghost stories, Alex's friends already were aware of the ghosts' influence on the radio - an element often associated with ghost presence in popular culture. The characteristic white noise, e.g. the uncomfortable cracks on the radio, adds to the atmosphere of the supernatural mystery. Alex can use her radio, which is visualised above her head in green neon color. Using the radio influences not only the game's sound but also the image, creating an impression of screen malfunctions, intertwining the audio layer with the visual one. 
That unpleasant feeling often evoked by ghosts, ghouls, and other supernatural entities, especially when their presence is subtle and suspected rather than seen, is often connected with the concept of the uncanny. Its modern use has been widely ascribed to Sigmund Freud's essay from 1919 (Proulx et al., 2010, p. 817), although it would be unjust to omit the essay titled On the Psychology of the Uncanny which Wilhelm Jentsch wrote almost fifteen years earlier (1906). In both texts, the uncanny is described as an experience of anxiety caused when animate and inanimate objects become confused (Hollington and Kyprianou, 2007, p. 17.1) or the known becomes mixed with the unknown. As an example of the latter, Freud uses the experience of déjà vu, which, together with other kinds of repetitions, is one of the most common phenomena causing the uncanny (Punter, 2007, p. 129). The most striking but also the most straightforward example of experiencing the uncanny is the encounter with the undead in a Gothic story; in the most obvious way, they represent the transgression between the binarities of life and death, familiar and unfamiliar.

In psychology, the equivalent of the uncanny could be found in the concept of "cognitive dissonance" (Festinger, 1962, p. 93) - an unpleasant state of psychological tension manifested as a result of a conflict between one's beliefs and behaviors, or between two contradictory judgments. Thus, the dissonance can be described primarily in terms of psychological discomfort, which, in its consequence, acts as an important bodily motivator. Similarly to the hunger pushing animals to find a source of food, it drives humans to change either the behavior or the belief (Elliot and Devine, 1994, p. 382). However, such change of behavior is more difficult in the case of the uncanny due to its extrinsic positioning, thus depriving the person of the control over the situation and creating a dissonance. The fear is a result of that discomfort, and the lack of other reactions at disposal of the person. Authors writing on the uncanny often emphasize that the term itself is as inconsistent and ambiguous as the phenomenon itself (Holmes, 2010, p. 256).

\section{Transgressions and the augmented reality of 0xenfree}

Despite the game's rather linear narrative, the players' actions influence the lives of the characters after they leave the island. Alex narrates the 
final events offscreen while the portraits of the characters show, together with the statistics comparing the choices against the other players' outcomes. Arguably, this sequence grants the illusion of players' agency and the meaningfulness of their choices, which, however, can be further questioned when it is revealed that Alex and other characters have never in fact left the island, instead being imprisoned in a time loop. There, in the game plus, after a replay, one can send a message back in time and warn Alex not to come to the island, thus breaking the ghost curse. Such branched narrative and nonlinearity, just like tales within tales, interpolated stories and other framing devices, again reflect the Gothic aesthetics, which, according to Eve Kosofsky Sedgwick, is "discontinuous and involuted" (Chess, 2017, p. 388).

The Gothic is a genre with major potential for transgressive narratives: it often plays with and against traditional gender roles and unconscious, often ignored fears. In the video game context, the types of transgression vary and can depend on the player's motivation and the area of the game where they occur. Holger Pötzsch (2018) identifies seven different types of video game transgressions: ludic, diegetic, critical, hegemonic, juridical, situational, and idiosyncratic. Nonetheless, Oxenfree does not seem to meet any of the criteria since Pötzsch's categories concentrate mostly on the players' agency. The transgressions often take place on the social level through the creation and actions of specific guilds, including queer ones (Sundén, 2013, p. 171). Another important example includes the political actions, including the many types of queer play (Ruberg, 2010, p. 109), and the pacifistic methods of beating the otherwise violent games. Some examples may include mastering the so-called "speedruns" and finding ways to beat the game as fast as possible (Smith et al., 2013, p. 132), as well as various methods of cheating, whether through exploiting glitches or using the "cheat codes". A famous example of the glitch use is the warthog jumping method discovered by a Halo player, allowing the players to access parts of the landscape not designed to be seen (Aarseth 2007, p. 132). It is interesting, however, to notice the role of glitch in Oxenfree. Despite its important function glitch usually has in facilitating the acts of ludic transgression, in this case it is a part of the aesthetic and narrative layer rather than the ludic one. By making glitch purposeful and reliable, it is being stripped of its subversive and transgressive 
potential. Instead, it symbolizes the otherworldly nature of the ghosts as transgressive - again, in the sense of crossing the boundaries.

However, transgressions can also be understood as subversions of expectations towards the genre (Jørgensen, Karlsen, 2018). Here, the looped ending plays on the expectation which dictates where the game should end. The game further crosses over, engaging the players on the socials and global levels. Although Oxenfree is not an augmented reality game, its developers engaged the players in a meta-game reaching beyond the in-game narrative. Fans discovered an encoded message hidden in the distorted, glitched radio frequencies found in the game, which pointed them to a Twitter account. Subsequently, following his interest and enthusiasm towards the game, an American Youtuber, Jesse Cox, received and uploaded a trailer which, unlike its previously released versions, included glitched images at the end revealing several red letters. Those led the fans to another site which was a clue leading to the location in Fort Ward in Washington where a box was hidden. According to the information posted on the forums, it contained letters written by Alex from all the alternate universes from the game and a tape player including the music from the game (Hester, 2016).

In this case, the augmented reality elements were not a part of the game in the sense that they were not required in order to complete it, but it is difficult to omit them when discussing the transgressive elements of the game. Despite the game's short length and the seeming straightforwardness of the plot, soon it reveals its many layers. The omnipresent glitch is more than just an aesthetic choice, betraying the game's many transgressions. On the narrative level, there are ghosts who cross from one world to another, from the incorporeal to corporeal upon possession. On an aesthetic level, the artistic glitch connects the audiovisual elements. Finally, the game subtly blurs the line between the game and the real world. Thus, the glitch becomes a visual representation of the uncanny.

\section{Conclusion}

Despite the scarcity of video game titles that could be classified as Gothic, the discussed medium allows for different new forms of actualization of the features of the genre. Oxenfree follows many characteristic tropes, 
including the strong female protagonist, haunted mansion, and the presence of malicious ghosts whose presence and the uncanny feeling they cause manifests through the use of glitch. Furthermore, the transgressions which are often found in Gothic narratives can be traced to the open ending and the framing device of the ghosts' curse trapping the protagonist in the narrative. By engaging the players on social media, the game transcends the borders of the digital artefact and creates a new experience with the potential of bonding the fan communities.

Furthermore, the small changes to the second playthrough, such as the ghosts who seem to remember the player and their experiences from the first run, bring to mind such fourth wall breaking games as Undertale (2015) or The Stanley Parable (2013). Both play with the player's expectations and their awareness of the game more boldly than it has been done before. By playing with time, Oxenfree subverts the player's expectations, blurring the line between the in-game world and the player's one.

\section{References}

Aarseth, E. (2014). I Fought the Law: Transgressive Play and the Implied Player. In N. Segal \& D. Koleva (Eds.), From Literature to Cultural Literacy (pp. 180-188). London: Palgrave Macmillan UK.

Baelo Allué, S. (2003). Blurring Posthuman Identities: The New Version of Humanity Offered by Bicentennial Man. ODISEA. Revista de Estudios Ingleses, 4, 17-30.

Betancourt, M. (2017). Glitch Art in Theory and Practice: Critical Failures and Post-Digital Aesthetics. New York: Routledge.

Chess, S. (2015). Uncanny Gaming. Feminist Media Studies, 15(3), 382-396. Edwards, J. D. (2017). Contemporary American Gothic. In J. A. Weinstock (Ed.), The Cambridge Companion to American Gothic (pp. 71-84). Cambridge, United Kingdom; New York, NY: Cambridge University Press.

Elliot, A. J., \& Devine, P. G. (1994). On the Motivational Nature of Cognitive Dissonance: Dissonance As Psychological Discomfort. Journal of Personality and Social Psychology, 67(3), 382-394.

Festinger, L. (1962). Cognitive Dissonance. Scientific American, 207(4), 93-106. 
Freud, S., Strachey, J., Cixous, H., \& Dennomé, R. (1976). Fiction and Its Phantoms: A Reading of Freud's Das Unheimliche (The "uncanny"). New Literary History, 7(3), 525-645.

Hayles, N. K. (1999b). How We Became Posthuman: Virtual Bodies in Cybernetics, Literature, and Informatics. Chicago, Ill: University of Chicago Press.

Hester, Blake (2016, 9 June). The Oxenfree Alternate Reality Game You Probably Didn't Know About. Retrieved from <https://killscreen.com/articles/oxenfree-alternate-reality-game-probably-didnt-know/>.

Hollington, S., \& Kyprianou, K. (2007). Technology and the Uncanny, 17.1-17.10.

Holmes, E. G. (2010). Strange Reality: On Glitches and Uncanny Play. Eludamos. Journal for Computer Game Culture, 4(2), 255-276.

Jentsch, E. (1997). On the Psychology of the Uncanny (1906). Angelaki, 2(1), 7-16.

Jørgensen, K. \& Faltin Karlsen. (2018). Introduction. In Transgressions In Games and Play (pp. 1-9). Cambridge, London: The MIT Press.

Oshii, M. (1995). Ghost In The Shell: Movie. Palm Pictures.

Pötzsch, H. (2018). Forms and Practices of Transgressivity in Videogames. In Transgressions In Games and Play (pp. 46-62). Cambridge, London: The MIT Press.

Proulx, T., Heine, S. J., \& Vohs, K. D. (2010). When Is the Unfamiliar the Uncanny? Meaning Affirmation After Exposure to Absurdist Literature, Humor, and Art. Personality and Social Psychology Bulletin, 36(6), 817-829.

Punter, D. (2007). The uncanny. In C. Spooner \& E. McEvoy (Eds.), The Routledge Companion to Gothic (pp. 129-136). London - New York: Routledge.

Ruberg, B. (2015). No Fun: The Queer Potential of Video Games that Annoy, Anger, Disappoint, Sadden, and Hurt. QED: A Journal in GLBTQ Worldmaking, 2(2), 108-124.

Smith, T., Obrist, M., \& Wright, P. (2013). Live-streaming Changes the (Video) Game. In Proceedings of the 11th European Conference on Interactive TV and Video (pp. 131-138). New York, NY, USA: ACM.

Spooner, C., \& McEvoy, E. (Eds.). (2007). The Routledge Companion to Gothic. London - New York: Routledge. 
Sundén, J. (2013). A Queer Eye on Transgressive Play. In J. Sundén \& M. Sveningsson, Gender and Sexuality in Online Game Cultures: Passionate Play (pp. 171-190). New York: Routledge.

Therrien, C. (2009). Games of Fear: A Multi-Faceted Historical Account of the Horror Genre in Video Games. In: B. Perron (ed.), Horror Video Games: Essays on the Fusion of Fear and Play (pp. 26-45). Jefferson, N.C.: McFarland.

Wachowski, L., \& Wachowski, L. (1999). The Matrix. Warner Home Video.

\title{
Ludography
}

Call of Cthulhu [Computer software]. (2018). Nanterre: Cyanide.

Oxenfree [PlayStation 4 software]. (2016). Glandale: Night School Studio. Toby Fox (2015). Undertale [Computer software]. Boston: Toby Fox. Vampyr [Computer software]. (2018). Paris: Dontnod Entertainment. Wreden, Davey (2013). The Stanley Parable [Computer software]. Galactic Cafe.

Agata Waszkiewicz, M.A. - psychologist, literary researcher, Ph.D. student at the Institute of English Studies, Maria Curie-Skłodowska University in Lublin

\section{Glitch jako symbol niesamowitości w Oxenfree (2016)}

\begin{abstract}
Abstrakt: Gotyk, jako gatunek literacki, wciąga swoich graczy w grę, wywołując w nich ten sam niepokój, który często odczuwająjego bohaterowie. Ponadto nierzadko ważny jego element stanowi transgresywność, przejawiająca się chociażby w elementach nadprzyrodzonych. Na szczególną uwagę zasługują tutaj duchy, wywołujące uczucie niesamowitości spowodowane przez spotkanie znanego z tym, co obce. Na element ten często trafić można w grach wideo. W artykule przyjrzę się grze Oxenfree (2016), wskazując na jej gotyckie elementy oraz ukazując, w jaki sposób niesamowitość przejawia się poprzez audiowizualny glitch.
\end{abstract}

Słowa kluczowe: Oxenfree, glitch, gracz transgresywny, niesamowitość 